\title{
Reflexões contemporâneas à luz da pandemia do novo coronavírus
}

\author{
Contemporary reflections in the light of the new \\ coronavirus pandemic
}

\author{
Reflexiones contemporáneas a la luz de la pandemia \\ del nuevo coronavirus
}

\begin{abstract}
A CRUEL PEDAGOGIA DO VÍRUS. Sousa Santos B. Coimbra: Almedina; 2020. 32 p. ISBN 978972-40-8496-1.
\end{abstract}

doi: 10.1590/0102-311X00108820

A obra de Boaventura de Sousa Santos 1, sociólogo e bacharel em Direito, propõe uma reflexão sobre o que podemos aprender com a pandemia de coronavírus do ponto de vista socioeconômico. A obra apresenta relevada importância para diversas áreas do conhecimento, entre elas a Saúde Coletiva, na medida em que contribui para o pensamento sobre a capacidade dos países de alterarem as suas políticas de saúde para responderem efetivamente à crise contemporânea do novo coronavírus.

O livro está dividido em cinco capítulos. No primeiro capítulo, intitulado Vírus: Tudo o Que é Sólido se Desfaz no Ar, discute-se que o ordenamento neoliberal e o modelo capitalista têm orientado o mundo a recrudescer políticas públicas de investimento em áreas como saúde, educação e previdência social, deixando o mundo em constante estado de crise, o que se acentua com a pandemia do novo coronavírus.

Chama-se atenção para o fato de que a pandemia, no entanto, põe diante dos olhos das democracias um "novo mundo" que busca aumentar o controle sobre a vida e a morte. O tempo passa a ter outra conotação, demonstrando haver possibilidades de uma reorientação sobre os modos de ser e estar no mundo, excluído do radar das sociedades hipercapitalizadas que, diante de situações pandêmicas, acabam entrando pela "porta dos fundos" para responder às novas necessidades.

Para o autor, a pandemia não é cega e possui "alvos privilegiados", o que induz à busca de soluções diferentes entre aqueles que possuem capitais sociais distintos. No entanto, apesar dos diferentes recursos sociais que as populações possuam, a receita do momento é genérica: manutenção do isolamento social, que implica redução de atividades econômicas e, consequentemente, menor carga de destruição da natureza.

Por fim, o capítulo também analisa, a partir da perspectiva da sociologia das ausências, a vulnerabilidade a que estão submetidas milhares de pessoas que permanecem invisíveis diante das respostas globais.

O segundo capítulo, intitulado A Trágica Transparência do Virus, aborda que a preocupação com a pandemia, em sociedades capitalistas, tem sido do ponto de vista econômico e não social, uma vez que o capital assume a posição de ser o todo-poderoso que norteia as relações sociais e políticas.

A pandemia, para Sousa Santos, repercute no modelo de economia capitalista neoliberal orientado para privatização e lei do mercado, expondo que os países que mais privatizaram a saúde são aqueles que enfrentam mais dificuldades de contingenciamento da pandemia, como os Estados Unidos. 
Nesse cenário, a pandemia assume função alegórica à medida que traz à tona possibilidades de interpretação da realidade ou de pensamentos que sustentam as relações sociais e que, até então, estavam no campo da invisibilidade, especialmente as formas articuladas de dominação dos três unicórnios sociais: capitalismo, colonialismo e patriarcado. Em conjunto, eles formam uma tríade poderosa que atua sobre a lógica de organização e funcionamento das sociedades.

O cenário da pandemia torna transparente a visão binária capitalista (superiores e inferiores) que reforça as disparidades sociais, legitimando a má distribuição de riquezas, a manipulação de pensamentos, a dominação cultural, a exploração capitalista, a existência de desigualdades sociais e dos modos de vida que colocam em risco a sobrevivência da humanidade e do planeta.

Atrelado a essa perspectiva do campo político, o autor chama atenção que a pandemia revela o esvaziamento da mediação dos intelectuais no que tange à produção de suas teorias e de suas teorizações e o alcance destas em relação aos anseios e necessidades dos cidadãos em suas vidas cotidianas, visto que a maioria dos intelectuais pensa e produz sobre o mundo, mas não pensa e produz com o mundo.

O terceiro capítulo, intitulado A Sul da Quarentena, discute a experiência da quarentena imposta pela pandemia do novo coronavírus e aquela que grupos vulnerabilizados pela discriminação racial, sexual e pela exploração capitalista, denominados metaforicamente pelo autor como sul, já vivem em detrimento das suas condições de vida. Para o autor, toda quarentena é discriminatória; difícil para alguns e impossível para outros e, por isso, se propõe a analisá-la a partir da perspectiva de mulheres, idosos, crianças, pessoas em situação de rua, imigrantes sem documentos, trabalhadores precários e informais, moradores de periferias e deficientes.

Ao analisar a quarentena sob a ótica desses grupos, o autor propõe uma reflexão sobre as recomendações de autoisolamento e distanciamento social promovidas pela Organização Mundial da Sáude (OMS). Embora essas recomendações possam ser efetivas para a classe média, não contemplam os cidadãos submetidos a condições de discriminação, injustiça social e sofrimento, de modo que as ausências de suas liberdades individuais, de direito à cidadania, ao cuidado de si, à cidade e ao trabalho formal que lhes garantam renda para a manutenção das mínimas condições de higiene e alimentação lhes expõem diariamente ao maior risco de contaminação pelo vírus.

$\mathrm{Na}$ medida em que alguns grupos têm permanecido à margem de direitos básicos, o autor argumenta que eles já vivenciam historicamente quarentenas em seus cotidianos e também propõe reflexões sobre esses períodos que representam os seus modos de vida. Por fim, chama atenção para o fato de que, contrariamente ao que é evidenciado pela mídia e organismos internacionais, a quarentena não somente evidencia esses grupos, como agudiza a injustiça e o sofrimento que vivem.

No quarto capítulo, intitulado A Intensa Pedagogia do Vírus: As Primeiras Lições, o autor aponta e analisa seis lições que, no mínimo, podem ser extraídas do cenário da pandemia como aprendizagens possíveis: Lição 1: o tempo político e "mediático" condiciona o modo como a sociedade contemporânea se apercebe dos riscos que corre; Lição 2: as pandemias não matam tão indiscriminadamente quanto se julga; Lição 3: enquanto modelo social, o capitalismo não tem futuro; Lição 4: a extrema-direita e a direita hiper-neoliberal ficam definitivamente (espera-se) descreditadas; Lição 5: o colonialismo e o patriarcado estão vivos e reforçam-se nos momentos de crise aguda; Lição 6: o regresso do Estado e da comunidade.

Por meio dessas seis lições, é feita uma abordagem sobre o "aprender com a pandemia". Também se aborda a articulação entre a pandemia e os problemas mais antigos (como sociais e ecológicos) que a humanidade enfrenta e que se tornam acirrados e visíveis em tempos de crise especialmente devido aos limites impostos ao Estado pelo capitalismo neoliberal advindo da política de privatização dos serviços de saúde, por exemplo.

A obra chama atenção que a busca por respostas a momentos e situações de crise se dá de formas diferentes, conforme os interesses econômicos e políticos que sustentam os modelos de sociedades neoliberais, cuja hegemonia social e política está fundamentada em concepções de extrema-direita e da direita hiper-neoliberal. Essas concepções têm passado por processos de descrédito à medida que as pessoas têm tomado consciência de seus objetivos financeiros e suas trágicas consequências globais, ao passo que o colonialismo e o patriarcado continuam exercendo poder e encontram terreno fértil para se fortalecerem em crises agudas. Em linhas gerais, as seis lições apontadas por Boaventura colocam 
em questão como fatores culturais, políticos, econômicos, sociais e ideológicos atuam como determinantes sociais da saúde e podem colocar populações em risco.

No quinto capítulo, intitulado O Futuro Pode Começar Hoje, discute-se a necessidade que as sociedades terão de se adaptar ao futuro, a fim de evitar que surjam novas pandemias tão ou mais letais quanto a atual. Ênfase especial é dada à reflexão sobre quais alternativas serão encontradas: se aquelas que buscam o retorno ao antigo normal ou aquelas que buscam a promoção do bem viver, a partir de mudanças nos modos de produção e consumo.

Para o autor, é necessária a rearticulação entre processos políticos e civilizatórios clivados a partir da queda do Muro de Berlim que pôs fim, a partir do norte global, às ideias de busca por alternativas à lógica capitalista e neoliberal que reduziriam as agressões à natureza e tornariam menos prováveis o surgimento de epidemias e pandemias.

Por fim, o autor salienta a necessidade de a humanidade se tornar mais humilde diante do planeta, entendendo que representa apenas $0,01 \%$ de toda a vida existente e de promover uma "virada" epistemológica, cultural e socioeconômica capaz de superar a quarentena imposta pela ordem capitalista vigente.

Em conclusão, a obra de Boaventura suscita a discussão de temas globais, emergentes e caros para as Ciências Sociais e Econômicas, assim como para a Saúde Coletiva, adquirindo grande relevância para a leitura e interpretação sobre a realidade e as implicações das pandemias nas diversas sociedades, especialmente em contextos capitalistas.

Teófanes de Assis Santos 1

Hélio Souza de Cristo 2

1 Instituto de Saúde Coletiva, Universidade Federal da Bahia, Salvador, Brasil.

2 Programa de Pós-graduação em Difusão do Conhecimento, Universidade Federal da Bahia, Salvador, Brasil.

teo.assis@hotmail.fr

\section{Colaboradores}

Os autores participaram igualmente da redação e da revisão final do texto.

\section{Informações adicionais}

ORCID: Teófanes de Assis Santos (0000-00032055-7677); Hélio Souza de Cristo (0000-00031219-9304).

\section{Referências}

1. Sousa Santos B. A cruel pedagogia do vírus. Coimbra: Almedina; 2020.
Recebido em 03/Mai/2020

Aprovado em 11/Mai/2020 